\title{
Brazilian recreational fisheries: current status, challenges and future direction
}

\author{
K. M. F. FREIRE
}

Departamento de Engenharia de Pesca e Aquicultura, Laboratório de Ecologia Pesqueira, Universidade Federal de Sergipe, São Cristóvão, Sergipe, Brazil

\section{R. A. TUBINO \& C. MONTEIRO-NETO}

Instituto de Biologia, Universidade Federal Fluminense, Rio de Janeiro, Brazil

\author{
M. F. ANDRADE-TUBINO
}

Universidade Veiga de Almeida, Rio de Janeiro, Brazil

C. G. BELRUSS, A. R. G. TOMÁS \& S. L. S. TUTUI

Laboratório de Estudos Estuarinos, Instituto de Pesca, Centro APTA Pescado Marinho, Santos, São Paulo, Brazil

P. M. G. CASTRO \& L. S. MARUYAMA

Laboratório de Ecologia e Pesca Continental, Centro de Pesquisas e Desenvolvimento em Recursos Hídricos, Instituto de Pesca, São Paulo, Brazil

\section{A. C. CATELLA}

EMBRAPA Pantanal, Corumbá, Mato Grosso do Sul, Brazil

\section{V. CREPALDI}

Instituto Brasileiro do Meio Ambiente e dos Recursos Renováveis (IBAMA), Núcleo de Ecossistemas Aquáticos, Belo Horizonte, Minas Gerais, Brazil

\section{R. A. DANIEL}

Departamento de Estatística e Ciências Atuariais, Universidade Federal de Sergipe, São Cristóvão, Sergipe, Brazil

M. L. MACHADO

IBAMA, Campo Grande, Mato Grosso do Sul, Brazil

\section{J. T. MENDONÇA}

Instituto de Pesca, Centro APTA Pescado Marinho, Núcleo de Pesquisa e Desenvolvimento do Litoral Sul, Cananéia, São Paulo, Brazil 


\title{
P. S. MORO
}

Moro Indústria de Artigos Esportivos Ltda, Curitiba, Paraná, Brazil

\author{
F. S. MOTTA \\ Departamento de Ciências do Mar, Universidade Federal de São Paulo, Santos, São Paulo, Brazil
}

\section{RAMIRES}

Laboratório de Ecologia Humana, Fisheries and Food Institute, Universidade Santa Cecília, Santos, São Paulo, Brazil

\author{
M. H. C. SILVA
}

UNIFESO, Centro de Ciências e Tecnologia, Engenharia Ambiental e Sanitária, Teresópolis, Rio de Janeiro, Brazil

\section{J.P. VIEIRA}

Instituto de Oceanografia, Universidade Federal do Rio Grande, Rio Grande do Sul, Brazil

\begin{abstract}
Recreational fisheries in Brazil have increased in importance and attracted many foreign recreational fishers. The objectives of this article were to summarise the available data on Brazilian recreational fisheries, to discuss some of their features and to analyse how they are performing in different regions compared with international trends. A review of published and unpublished sources together with data from recreational fishing licences was used. The participation rate was low $(0.9 \%)$. Overall, there was a high diversity of fish species, with the following species/group of species repeatedly reported: Menticirrhus spp., Centropomus spp., Cynoscion spp., and Micropogonias furnieri (marine/estuarine water), and Cichla spp., Hoplias malabaricus, and Piaractus mesopotamicus, together with the introduced Oreochromis niloticus and Coptodon rendalli (fresh water). The north-eastern region differs from the other regions: fishing occurs mostly in marine waters and fishers acquire mainly shore-based licences, have minimum fishing expenditures and rarely release fishes. There is no estimate of the total harvest or economic value. Conflicts include catch-and-release-oriented freshwater and marine recreational fishers vs consumption-oriented coastal fishers, tournament participants vs non-participants, commercial fishers and other leisure activities, pollution, ports, species introductions and translocations, protected areas, and federal and state laws. Cases of smooth shifts from artisanal to recreational fishing were detected, possibly associated with changes in the societal relationship with natural resources.
\end{abstract}

K E Y W OR D S : $\quad$ angling, competitive events, fisheries management, sport fisheries, tourism, tournaments.

\section{Introduction}

Brazil's ichthyofauna includes 3290 freshwater species and 1209 marine species (Froese \& Pauly 2015) representing $14 \%$ of global fish diversity. This high diversity is strongly related to the heterogeneity of habitats and climate and provides considerable recreational fishing opportunities. Zeinad and Prado (2012) listed 114 freshwater fish species of some interest for recreational fishers throughout the country. For marine waters, at least 60

Correspondence: Kátia de M. F. Freire, Departamento de Engenharia de Pesca e Aquicultura, Laboratório de Ecologia Pesqueira, Universidade Federal de Sergipe, Cidade Universitária Prof. José Aloísio de Campos, Rua Mal. Rondon S/N, Jardim Rosa Elze, São Cristóvão - Sergipe - Brazil, CEP 49100-000 (e-mail: kmffreire2015@gmail.com) 
recreational fish species are reported (Anon 2015). The recreational fishery (recreational fisheries) is locally defined as 'the one practiced by Brazilians or foreigners, with gears defined by specific law, for leisure or sport' (MPA 2009).

Recreational fisheries is largely recognised as a socioeconomically important activity in countries, such as the USA and Canada (e.g. Ihde et al. 2011), but is not fully recognised by governments in many emerging economies, including Brazil, despite its growing reputation as an international fishing destination. Thus, recreational fisheries remain mostly unmanaged or mismanaged in these regions.

The practice of recreational fisheries as a leisure activity in Brazil goes back to at least the 1800s, with the first citation in the book 'Viagem ao Araguaya' (Magalhães 1863). Fishing clubs have been active for many years. The first shore-based fishing events took place in the 1960s (Freire et al. 2014a,b) and oceanic competitive events have been promoted since 1962 off the state of Rio de Janeiro, including an international tournament in 1972 (Barroso 2002). Recreational spearfishing has also been practiced since at least 1970 (Anon 1970). The magazine Pescatur was the first one specialising in recreational fisheries and was launched in the early 1970s. The first scientific publications on recreational fisheries in Brazil came out in the 1990s (Arfelli et al. 1994; Lewis et al. 1999), which corresponded to the period when the visibility of this activity improved. Recently, recreational fisheries have increased in importance in Brazil and recreational catches have surpassed commercial catches in some areas (see, e.g., Catella et al. 2008).

Although studies on recreational fisheries have increased in the last few years, this information is dispersed and has not been collated. This contribution summarises available data on Brazilian freshwater and marine recreational fisheries, discusses some of their features and conflicts, and analyses how Brazilian recreational fisheries is performing in different regions compared with international trends.

\section{Methods}

In this study, two components of recreational fisheries are considered: non-competitive and competitive fishing (tournaments, jamborees and championships). For the former, Brazilian recreational fisheries were reviewed based on published and unpublished information (theses, reports and personal communications) in different habitats: freshwater (rivers, lakes and reservoirs) and marine (estuarine, coastal and oceanic). The region is divided into twelve basins as defined by the National Agency of Waters (www.ana.gov.br) and this division was used when referring to freshwater fisheries (Fig. 1): Amazonia (3 $\left.869953 \mathrm{~km}^{2}\right)$, Tocantins-Araguaia $\left(918822 \mathrm{~km}^{2}\right.$ ), Paraná $\left(879873 \mathrm{~km}^{2}\right)$, São Francisco $\left(638576 \mathrm{~km}^{2}\right)$, eastern Atlantic (388 $\left.160 \mathrm{~km}^{2}\right)$, Paraguay $\left(363446 \mathrm{~km}^{2}\right)$, Parnaíba $\left(333056 \mathrm{~km}^{2}\right)$, eastern north-east Atlantic $\left(286802 \mathrm{~km}^{2}\right)$, western north-east Atlantic $\left(274301 \mathrm{~km}^{2}\right)$, south-eastern Atlantic (214 $\left.629 \mathrm{~km}^{2}\right)$, southern Atlantic $\left(187522 \mathrm{~km}^{2}\right)$ and Uruguay (174 533 $\mathrm{km}^{2}$ ). To include marine fisheries, information was presented by administrative region (five) and all states within these regions (total of 25 states). Information on the characteristics of recreational fisheries, including a description of the marine and freshwater fisheries, demographic characteristics of licensed anglers, catch composition and catch rates, was collated. Froese and Pauly (2015) was consulted for scientific and English common names as well as species authority.

An updated version of the database originally compiled by Freire (2005) for marine events from 1970 to 2013 was used for competitive events. The database encoded by Santos and Freire (2014) for all Brazilian states was utilized for fresh waters.

The 2013 database of the Ministry of Fisheries and Aquaculture (MPA) was used for analysis of licences, with the following selected variables: region (north, centre-west, north-east, south-east and south), state, sex, use of natural and/or artificial bait, catch-and-release habits, expenditure, licence type (according to Freire et al. 2012), boat ownership, use of fishing guides, fishing habitats (estuarine, coastal, oceanic, mangrove, lake, reservoir, river and fish-and-pay) and hosting location. The licence database was analysed using a multivariate correspondence analysis - CA (Greenacre \& Blasius 1994) performed in $R$ software ( $R$ Core Team 2014). The relationship between catch-and-release habits (proportion of licensed fishers that usually or sometimes release fishes from the 2013 licence database) and the human development index (HDI) (PNUD/IPEA/FJP 2013) was analysed for all Brazilian states.

Finally, the general legal framework for recreational fisheries in Brazil was described, and some conflicting issues were analysed. Based on comparison of all information presented, future directions for this sector are discussed.

\section{Characteristics of recreational fisheries in Brazil}

\section{Northern region (states of Amazonas, Pará, Roraima, Amapá, Rondônia, Acre and Tocantins)}

This region, mostly included in the Brazilian Amazonia, emerged as a more recent destination for recreational fisheries in Brazil, which led to the promotion of the 


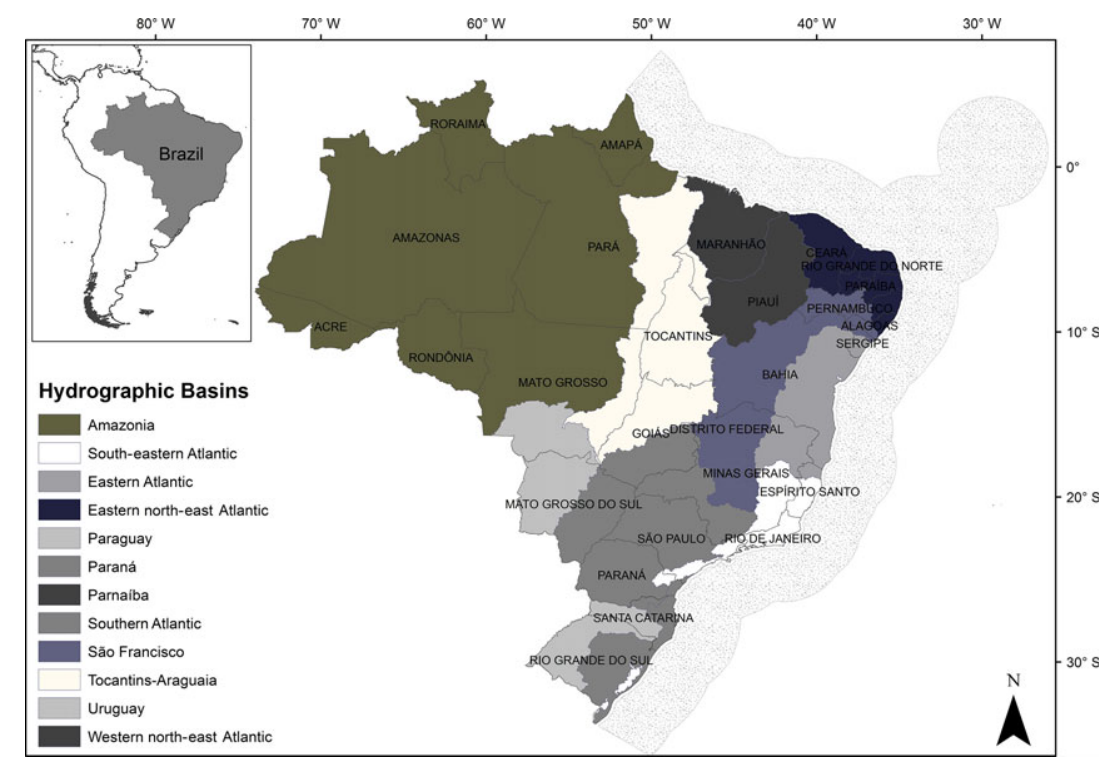

Figure 1. Twelve Brazilian basins, as defined by the National Agency of Waters (www.ana.gov.br), all of Brazilian states and the Exclusive Economic Zone (EEZ; greyish dotted area).

First Workshop on Recreational Fishery in the state of Amazonas in 2000 (IPAAM 2001). The main target species is the peacock bass (Cichla spp.; see Table S1). The average expenditure by visiting fishers is US\$ 3000 for a 7-day trip (October to March) (Freitas \& Rivas 2006). Other target species are the following: Osteoglossum spp., Hypophthalmus spp., Brycon cephalus (Günther), Brachyplatystoma spp., Pellona spp., Boulengerella spp., Hydrolycus scomberoides (Cuvier) and Raphiodon vulpinus Spix \& Agassiz (IPAAM 2001). Most of the operations in the region are based on hotel boats, but in some areas with difficult access, fishers arrive by hydroplanes and stay overnight in tents mounted on floating structures. Hotels and jungle lodges are also used (Barra \& Crepaldi 2014). Catch-and-release is the dominant practice among national and foreign recreational fishers in the region. Thomé-Souza et al. (2014) estimated very low mortality rates for three species of Cichla, including C. temensis Humboldt (3.5\%), C. orinocensis Humboldt (2.3\%) and C. monoculus Agassiz (5.2\%), in the basin of the Negro River, which is the largest tributary of the Amazon River.

According to the Amazon State Enterprise for Tourism (Amazonastur), the number of fishing tourists visiting the state of Amazonas has been increasing and reached 7293 in 2011 (Santos undated). A total of 33 recreational fisheries operators were identified in 20132014 in all tributaries of the Negro River, according to the Participative Fishery Monitoring Project developed by the Social and Environmental Institute (ISA 2013). Groups are usually formed of 6-15 fishers and $11 \%$ are foreigners. Approximately $50 \%$ of these fishers complain about the lack of local infrastructure and surveillance (Barra \& Dias 2013).

Despite the high catch-per-unit-effort (CPUE) that is usually reported for the Brazilian Amazonia, fishing pressure has been very intense due to the lack of planning, monitoring and surveillance. The lack of planning leads to a massive exploitation in some areas while others remain under-utilised. The lack of monitoring induces a high fishing effort that can result in overexploitation of some stocks (decreasing CPUE and fish size). Local recreational fishers have continuously complained about both decreasing CPUE and fish size (Daniel Crepaldi, personal observation), although this effect has not been quantified. Since the 1990s, this has led to the search for unexploited regions in the so-called Legal Amazon and in Protected Natural Areas (PNAs, both Conservation Units and Indigenous Lands) when conflicts arose due to the lack of proper regulation. Since 2009, the Brazilian Institute for the Environment and Renewable Resources (IBAMA) has begun standardised fish stock assessments for the dominant recreational fisheries species in five rivers to propose rules for sustainable use of their resources (see Crepaldi \& Machado 2010). These studies confirmed that fish stocks in the PNAs were healthier than those outside the PNAs.

In the state of Pará (Fig. 1), both marine and freshwater recreational fisheries take place and the main target species/groups of species are: Cichla spp., Hoplias malabaricus (Bloch), Characidae, Micropogonias furnieri (Desmarest), Cynoscion acoupa (Lacepède) and 
Plagioscion squamosissimus (Heckel) (Frédou et al. 2008). A study with 114 marine and freshwater recreational fishers showed that $70 \%$ live in the state of Pará and none was foreigner (Frédou et al. 2008). This study also indicated that the state of recreational fisheries was satisfactory with many unexploited areas. Spearfishing was reported in fresh waters with up to $100 \mathrm{~kg}$ caught by one fishing group over a single night. According to that study, the lack of infrastructure, including roads, is one of the main obstacles to the development of recreational fisheries. There is also an increasing demand for fish-and-pay operations and the establishment of areas reserved for recreational fisheries may become an important source of conflicts.

For the state of Roraima, Salazar Filho et al. (2005) found potential for development of recreational fisheries along the lower Branco River: Água Boa do Univiní, Xeruiní and Itapará rivers. They caught mainly Cichla spp., Boulengerella spp., Serrasalmus spp. and Hoplias spp. and reported the existence of six lodges already operating with recreational fishers. No information was found for the other four states.

\section{Centre-western region (states of Mato Grosso, Mato Grosso do Sul and Goiás)}

The Pantanal is an extensive alluvial plain that encompasses $138183 \mathrm{~km}^{2}$ and is split between the states of Mato Grosso (48 $865 \mathrm{~km}^{2}$ ) and Mato Grosso do Sul $\left(89318 \mathrm{~km}^{2}\right)$, where fishing is a traditional activity of high socio-economic importance. Recreational fisheries are greater in the state of Mato Grosso do Sul (Southern Pantanal), for which most information is available since 1994, based on the Mato Grosso do Sul Fishing Control System (SCPESCA/MS) (Catella et al. 2008). Many local artisanal fishers have become fishing guides. Most of the recreational fishers are tourists from the southeastern and southern regions (Albuquerque et al. 2013), who use transportation and lodging services offered by regional tourism agencies including the services of luxurious hotel boats. The number of registered recreational fishers reached 59000 in 1999 but has declined to 14000 in recent years (Albuquerque et al. 2013).

Landing areas for recreational and artisanal fishers are widely spread over the southern Pantanal and thus are difficult to quantify. From 2007 to 2012, under a fishing quota of $10 \mathrm{~kg}$ per recreational fisher per trip plus one specimen, the annual median CPUE was $2.7 \mathrm{~kg}$ fish$\mathrm{er}^{-1}$ day $^{-1}$ (1.7-3.9 kg) (see Table S1). During the same period, under a monthly fishing quota of $400 \mathrm{~kg}$ per artisanal fisher, the annual median CPUE was $8.3 \mathrm{~kg}$ fish$\mathrm{er}^{-1}$ day $^{-1}(4.7-14.6 \mathrm{~kg})$. In 2012, a total of $173 \mathrm{t}$ $(51 \%)$ and $165 \mathrm{t}(49 \%)$ were caught by artisanal and recreational fishers, respectively. The main species caught by the latter were Pseudoplatystoma reticulatum Eigenmann \& Eigenmann, Piaractus mesopotamicus (Holmberg), Leporinus macrocephalus Garavello \& Britski, Pygocentrus nattereri Kner, Serrasalmus spp. and Pseudoplatystoma corruscans (Spix \& Agassiz). The overlap of species caught by recreational and artisanal fishers is complete, but recreational landings surpass artisanal landings for most species (Fig. 2). From 1980 onwards, some gears were prohibited to artisanal fishers and they started using hooks targeting larger species with higher market value, leading to the overlap with recreational fisheries and ultimately to conflicts (Catella 2007). Another conflict observed is the exclusion of both recreational and artisanal fishers from long stretches of protected areas in local rivers. There has also been an increasing demand for live bait by recreational fisheries, generating a new sector of specialised artisanal fishery and a certain degree of cooperation between artisanal and recreational fishers.

The rivers of the Amazon basin that drain the central and northern regions of the state of Mato Grosso are also an important destination for Brazilian and foreign recreational fishers, but there is little information available about this activity (Arrolho \& Muniz 2011). Teles Pires and Juruena rivers are among the main fishing destinations of the region. A survey conducted in 2010 by the City Hall of Alta Floresta, near the Teles Pires River,

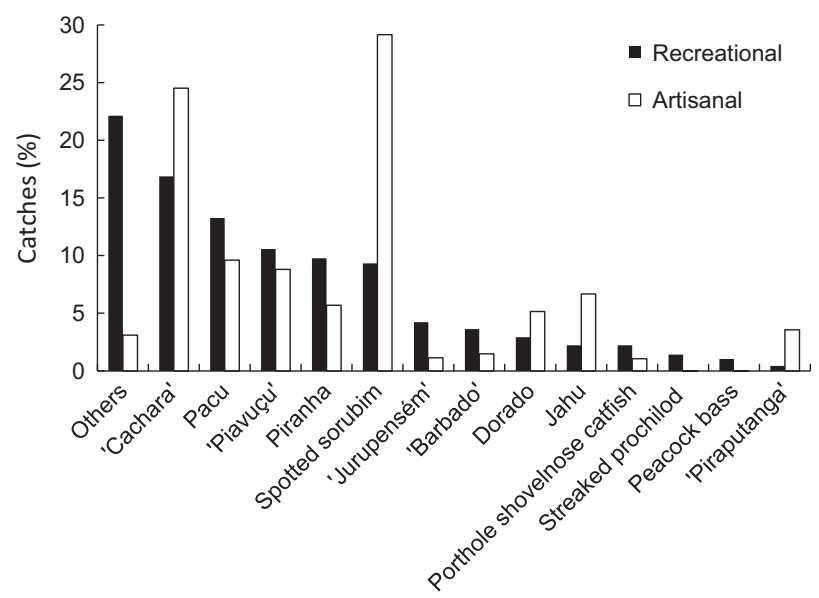

Figure 2. Proportion of each of the main species caught by recreational (black columns) and artisanal (white columns) fishers in Southern Pantanal in 2012 (based on Albuquerque et al. 2013). 'Cachara' = Pseudoplatystoma reticulatum (Eigenmann \& Eigenmann), 'Piavuçu' = Leporinus macrocephalus (Garavello \& Britski), 'Jurupensém' = Sorubim lima (Bloch \& Schneider), 'Barbado' = Pinirampus pirinampu (Spix \& Agassiz) and Luciopimelodus pati (Valenciennes), 'Jurupoca' $=$ Porthole shovelnose catfish $=$ Hemisorubim platyrhynchos (Valenciennes), and 'Piraputanga' $=$ Brycon hilarii (Valenciennes). 
indicated the existence of 18 recreational fisheries-related projects, generating approximately 1250 direct and indirect jobs and accounting for about $14 \%$ of the municipal revenues (Arrolho \& Muniz 2011). These authors conducted a monitoring programme of fish populations in the Teles Pires River over 3 years using the same gears locally used by recreational fishermen. The most common species/group of species caught were Cichla spp. (53.0\%), Zungaro zungaro (18.3\%), Phractocephalus hemioliopterus (Bloch \& Schneider) (9.3\%) and Pseudoplatystoma tigrinum (Valenciennes) (3.0\%).

Some indigenous lands have become fishing destinations in the Amazon basin of Mato Grosso, generating many conflicts between government institutions (e.g. IBAMA), indigenous populations (e.g. Bakairi and Kayabi) and tourism agencies. Some recreational fishers, tourism agencies and irregular hostels have been fined and prohibited fishing gears and boats have been seized after complaints from indigenous people (IBAMA 2012, 2014). Three hydroelectric plants are under construction in the Teles Pires River in Alta Floresta, which will probably affect its fishing potential (Arrolho \& Muniz 2011).

For the state of Goiás, Carvalho and Medeiros (2005) interviewed 40 recreational fishermen in 20032004 along the Araguaia River and found a CPUE of $3.2 \mathrm{~kg}$ fisherman ${ }^{-1}$ day $^{-1}(\mathrm{SD}=1.7 \mathrm{~kg})$. Twenty one fish species/groups of species were caught and the main ones were: Pimelodus maculatus Lacepède, Triportheus angulatus (Spix \& Agassiz), Leporinus spp., Plagioscion spp. and Tetragonopterus argenteus Cuvier. All of the fishes caught are consumed by fishers, indicating that catch-and-release is not a popular practice. The estimated economic value of this river in terms of recreational fisheries was US\$ 6.3 billion (Angelo \& Carvalho 2007), which is probably an overestimate.

North-eastern region (states of Maranhão, Piauí, Ceará, Rio Grande do Norte, Paraíba, Pernambuco, Alagoas, Sergipe and Bahia)

Freire (2005), using questionnaires distributed among recreational fishers in fishing clubs/associations and shops, found that none of the respondents fished only in fresh waters, $38 \%$ were restricted to marine waters, and most of them fished in both areas. Thus, marine recreational fisheries are predominant, with most fishers engaged in coastal/estuarine fisheries.

There is no information on catch composition for non-competitive fishing. Nunes et al. (2012) analysed information on catch composition of spearfishing activities off the state of Bahia in 2006-2008. Forty-eight species were caught with dominance of Scomberomorus brasiliensis Collette, Russo \& Zavala-Camin, Sphyraena barracuda (Edwards), Lutjanus jocu (Bloch \& Schneider) and Caranx bartholomaei Cuvier (56\% of total catches). More recently, oceanic fisheries have increased in popularity in the states of Rio Grande do Norte, Paraíba, Pernambuco, Sergipe and Bahia (Gustavo Adelino, Zagaia Pesca Oceânica, personal communication).

Only one charter operation in fresh water was found in north-eastern Brazil, which recently started activities in the state of Sergipe and targets mainly snooks (Marcos Seabra, Sport Fishing Sergipe, personal communication). Another area that has attracted recreational fishers is the Castanhão Dam in the Jaguaribe River (state of Ceará). Its construction began in 1995 and took 8 years to be completed (Oliveira et al. 2014).

Many coastal and oceanic fishing events occur in the region and detailed information is provided below.

\section{South-eastern Region (states of Minas Gerais, Espírito} Santo, Rio de Janeiro and São Paulo)

The importance of recreational fisheries in the state of Minas Gerais has increased in recent years (Freire et al. 2012). However, no information on the characteristics of recreational fisheries in this state was found, except for the impact of the translocation of some species, such as Plagioscion squamosissimus (Sciaenidae) and Parachromis managuensis into the Doce River, which are expected to affect the native biodiversity negatively similar to other introduced species listed in Barros et al. (2012).

For the state of Espírito Santo, the only study found referred to coastal fisheries (Chiappani 2006). In 20052006, two of the 25 species caught were responsible for most of the catches, Conodon nobilis (L.) (17\%) and M. littoralis (14\%), despite the main target being Trachinotus spp. The mean CPUE reported was 2.3 and $36.6 \mathrm{~g}_{\text {fisher }}^{-1} \mathrm{~h}^{-1}$ on the beach and a pier, respectively, and shrimp was the main bait (52\%).

Most of the information available for the region refers to the states of São Paulo and Rio de Janeiro. With the growing crisis in commercial fisheries, some artisanal fishers have become fishing guides. Previous studies reported a strong overlap of target species between recreational and artisanal fishers in Guanabara Bay (M. furnieri, Cynoscion spp., Pomatomus saltatrix (L.), Caranx spp. and Priacanthus arenatus Cuvier, Tubino et al. 2007). However, considering the ten top species targeted by commercial fishers in the state of Rio de Janeiro (FIPERJ/MPA/UFRJ undated), only $M$. furnieri is of any interest for recreational fishers. 
In the state of São Paulo, catch statistics originating from industrial and artisanal fisheries have been reported since the 1940s (DPA 1946). Currently, the Fisheries Institute (Instituto de Pesca) is responsible for collecting information on commercial catches for the entire state. However, there is no collection system for recreational catches, except for some isolated initiatives. The Iguape and Cananéia Lagoon-Estuarine Complex (LEC), located in the southern part of the state of São Paulo where the highest number of artisanal fishers is found (Mendonça $\&$ Cordeiro 2010), has attracted a growing number of recreational fishers. The target species are Centropomus undecimalis (Bloch), C. parallelus Poey, Cynoscion leiarchus (Cuvier) and C. acoupa, with a mean CPUE of $2.8 \mathrm{~kg}$ fisher $^{-1}$ day $^{-1}$ (Moro et al. 2010). There is no management plan for recreational fisheries in this region, which has caused increasing conflicts (Mendonça \& Parada 2014). Only half of the recreational fishers have fishing licences and many of them are not aware of catch quotas and minimum size limits (Barcellini et al. 2013).

Recreational fisheries are also important in the coastal area adjacent to this LEC. Based on 16 recreational fishing operations monitored in 2009, 29 species were caught, but only a few represented most of the catches: Cynoscion microlepidotus (Cuvier), Scomberomorus brasiliensis, and Centropomus parallelus. Recreational fisheries are boatbased and usually involve three people (one guide plus two recreational fishers using rod-and-reel) (Garrone-Neto et al. 2014). Sardine (Clupeidae), squid (Loliginidae) and shrimp (Penaeidae) are the most commonly used bait in association with artificial lures.

Most of the marine recreational fishers in the southeastern region are elder males (41-50 years old) with monthly incomes of US\$ 1111-2222 (Barcellini et al. 2013; Tsuruda et al. 2013; Tubino et al. 2013; Belruss 2014). They go fishing for 6-24 h and spend US\$ 8.4083.12 per fishing day (Table 1 in the Supplementary Material). Usually, more than $25 \%$ of the recreational fishers do not have fishing licences.

Freshwater fishing in the state of São Paulo is practiced mainly in reservoirs and free stretches of major rivers. The number of recreational fishers has been increasing in reservoirs and rivers such as Paraná, Grande, Paranapanema, Tietê, Mogi-Guaçu and Pardo (Santos et al. 1995; Castro et al. 2006). Freshwater recreational fisheries are shore or boat-based. For boatbased activities, fishers rent boats and tackle, and hire fishing guides to fish in the former three rivers. In large dams (Jupiá, Barra Bonita and Promissão), commercial fishing is dominant, although recreational fishers are found over the weekends (Petrere et al. 2002). Fish-andpay is practiced in privately owned tanks or ponds (Castro et al. 2006) and represents an alternative for areas with intensive fishing pressure (Venturieri 2002). However, fish escapement may lead to the spread of non-native species (Fernandes et al. 2003). Agostinho et al. (2003) reported the occurrence of recreational fisheries throughout the year in the Upper Paraná River Basin where fishers target mainly Salminus maxillosus (Cuvier), Brycon orbignyanus (Valenciennes), P. mesopotamicus, Leporinus elongatus Valenciennes, Leporinus obtusidens (Valenciennes), P. corruscans and Zungaro zungaro (Humboldt). However, there are no data available on the yield of these fisheries.

According to Adalberto F. de Oliveira Filho (personal communication), a member of the Federation of Sport Fishing of the State of São Paulo (http://www.fppl.com.br/), peacock bass (Cichla spp.) is targeted by recreational fishers along the Tietê River and many other large rivers in 19 municipalities of the state of São Paulo. In this area, there are 211 lodges and recreational fisheries generate revenues of US\$ 305-570 million per year with over 4000 people directly employed (April/2014 survey). Information on catch composition is available for some reservoirs, such as LoboBroa and Emas Waterfall (Mogi-Guaçu), as well as Tietê, Paraná, Paranapanema and Grande rivers: Cichla spp., Geophagus brasiliensis (Quoy \& Gaimard), Coptodon rendalli (Boulenger), Oreochromis niloticus (L.), Gymnotus carapo L., H. malabaricus, Serrasalmus marginatus Valenciennes, Rhamdia quelen (Quoy \& Gaimard), Plagioscion squamossissimus (Heckel) and Salminus brasiliensis (Cuvier) (Peixer 2008; Pereira et al. 2008; Castro et al. 2009; AES-Tietê 2011; Maruyama et al. 2014).

Fisheries targeting live bait occur in flooded, shallow areas covered with vegetation along the slopes of rivers and reservoirs of the state of São Paulo. A total of 60 80 fishers are involved in catching at least 17 bait types along the Middle Tietê River but mostly Gymnotus spp., snail and shrimp (Castro et al. 2014). Fishers catch 200 specimens per day (US\$ 1.00-1.50 specimen $^{-1}$ ) and all specimens are sold alive directly to recreational fishers, indirectly through middlemen or even in live-bait shops.

The main problems are pollution (garbage, industrial and domestic sewage, and pesticides), the change in water level, a decline of fish stocks caused by high fishing effort, dam construction, unsustainable practices (such as capture of individuals below maturity size), and conflicts between commercial and recreational fishers, fishers vs the environmental police, and professional artisanal vs illegal fishers (Paula Gênova, personal observation).

\section{Southern Region (states of Paraná, Santa Catarina and Rio Grande do Sul)}

No published study was found dealing specifically with recreational fisheries in the state of Paraná. Nonetheless, 
in the estuarine region, boat-based fishers are observed with similar characteristics of neighbouring states (São Paulo and Santa Catarina). Thus, based on the similar catch composition in these states (Menezes et al. 2012; Barcellini et al. 2013), one expects that snooks (C. undecimalis and $C$. parallelus) and weakfishes (Cynoscion spp.) are also the main species caught in the estuaries of Paraná. Several competitive fishing events targeting snooks support this hypothesis (Moro 2008).

According to Deodato Pereira and Edson Deconto (personal communication), co-founders of the Association of Fishers with Artificial Lures from Paraná (APIAPAR) in the 1980 s, boat-based recreational fisheries are also practiced in dams along the Iguaçu River. In these dams, H. malabaricus, O. niloticus and C. rendalli are the main target species. Cichla spp. are targeted in the Itaipu Dam.

For the state of Santa Catarina, Schork et al. (2010) reported information on boat-based recreational fishers off the northern coast, who catch Menticirrhus spp., Coryphaena hippurus L., Orthopristis ruber (Cuvier), Sphyraena guachancho Cuvier, P. saltatrix and Trichiurus lepturus L. Fishers are mainly men, fish for 6-24 h, and most do not have a fishing licence $(75 \%)$. According to Menezes et al. (2012), 30 species were caught in estuaries by boat-based fishers, mainly $C$. undecimalis, C. parallelus and Cynoscion spp. Approximately $40 \%$ of these fishermen did not have a fishing licence.

The earliest published information on recreational fisheries for the state of Rio Grande do Sul was Lewis et al. (1999), who reported catches of 31 fish species/groups of species off the Cidreira Pier, mainly M. littoralis, M. americanus (L.), Paralonchurus brasiliensis (Steindachner), M. furnieri, sharks and rays (Carcharhinidae, Myliobatidae, Rhinobatidae, Rhinopteridae and Sphyrnidae). According to Peres and Klippel (2005), recreational fisheries are mainly shore-based and fishers use mostly a rod-and-reel, with some similarities between the northern and southernmost regions, where catches are dominated by juvenile Menticirrhus spp., with total annual recreational fisheries catches of 1.0-2.5 $\mathrm{t}$ in the latter (Basaglia \& Vieira 2005). The middle area is the least known and includes the Lagoa do Peixe National Park where recreational fisheries is not allowed, but it is very intense in the surf zone next to the park. Harayashiki et al. (2011) also included M. furnieri in the list of target species. Moreover, there are groups targeting rays and sharks during the night. Condini et al. (2007) found that Epinephelus marginatus (Lowe), a species included in the IUCN list, is caught by both recreational (19\%) and artisanal $(81 \%)$ fishers off the Patos Lagoon jetties $(73 \%$ of all specimens that were caught with a handline in Jan-Feb 2006 were juvenile females).

\section{Marine and freshwater competitive fishing events}

For marine events, which are usually promoted by fishing clubs/associations, the results are currently reported on their web pages and include the number of specimens caught, their total weight, and the number of points per fisher. Catches amounted to $6.5-7.9 \mathrm{t} \mathrm{yr}^{-1}$ during the period of higher catches (2002-2007) (Fig. 3). Most of the recreational competitions $(n=123)$ were held in 2007 (Fig. 4), which is certainly an underestimate. The results presented here are partial because the missing values were not estimated, except for events in the state of Sergipe (Freire et al. 2014a). Catch-and-kill is the main feature of these events, but there is no information on catches per species. However, organisers report the weight of the heaviest fish (168 common names, although $85 \%$ of the heaviest specimens had no associated name). Species/families with more than 100 records were as follows: Rajiformes, Tetraodontiformes, Ariidae, Polydactylus spp., Haemulidae, Menticirrhus spp., Carangidae, Trachinotus spp. and Eucinostomus spp.

Catches from oceanic competitive events targeting tuna and tuna-like fishes off the coasts of Rio de Janeiro, São Paulo and Espírito Santo include mainly Istiophorus platypterus (Shaw), C. hippurus, Thunnus albacares (Bonnaterre), Katsuwonus pelamis (L.), Makaira nigricans Lacepède, Acanthocybium solandri (Cuvier) and Kajikia albida (Poey) (Arfelli et al. 1994; Amorim \& Silva 2005; Amorim et al. 2009). Oceanic events have also been organised off the coasts of the states of Rio Grande do Norte, Pernambuco (including Fernando de Noronha Island) and Bahia (Freire et al. 2014a,b). However, no details on species composition have been reported.

A few studies were conducted to provide details on the catch composition of coastal competitive events. Only marine shore-based competitive fishing events are promoted in the municipality of Ilhéus (southern Bahia).

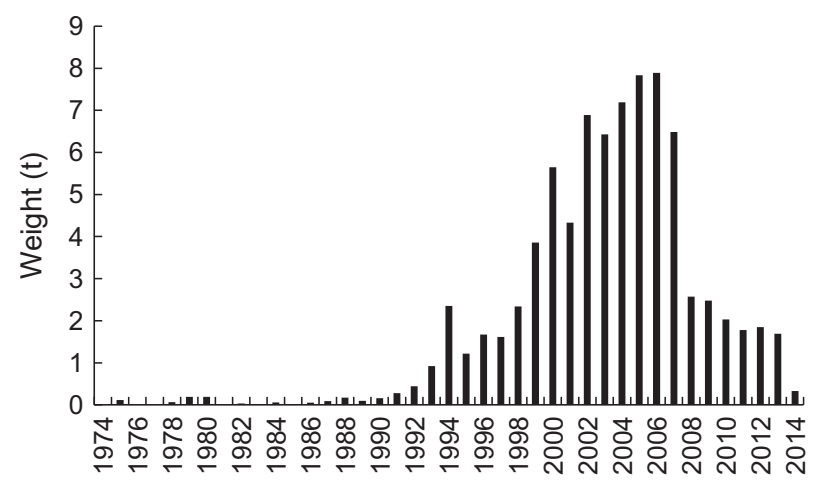

Figure 3. Weight of all of the specimens caught in fishing events conducted in marine waters off Brazil. 


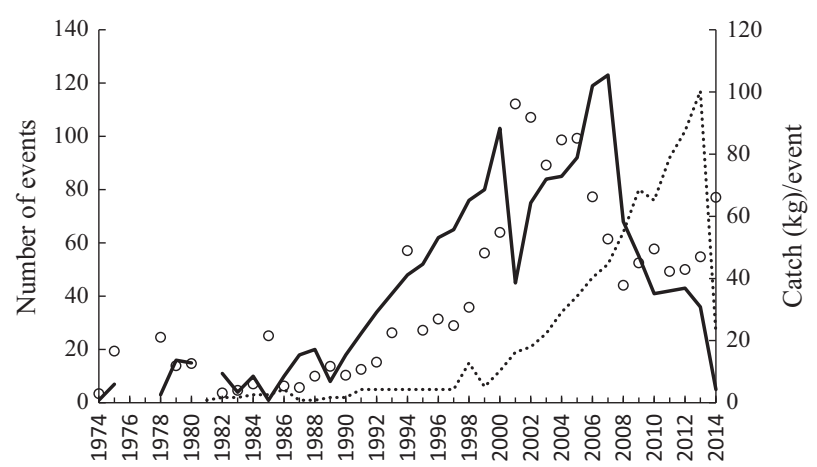

Figure 4. Number of fishing events in marine water (black line) and fresh water (dotted line), and catch (kg)/event (white circles) in 1974 2014 off Brazilian waters.

Nascimento (2008) analysed the catch composition of all of these events in 2007 and found that approximately $180 \mathrm{~kg}$ of Cathorops spp., Eucinostomus melanopterus (Bleeker), Trachinotus goodei Jordan \& Evermann, Menticirrhus littoralis (Holbrook), Atherinella brasiliensis (Quoy \& Gaimard), Genidens genidens (Cuvier) and Trachinotus carolinus (L.) among others, were caught (6043 specimens). In the state of Rio Grande do Norte, competitive events were promoted along the entire coast. According to Alves (2011), a total of $326 \mathrm{~kg}$ (6998 specimens) were caught in 2009 and were mainly represented by Pomadasys corvinaeformis (Steindachner), Sciades couma (Valenciennes), Dasyatis guttata (Bloch \& Schneider), M. littoralis and Colomesus psittacus (Bloch $\&$ Schneider). Freire et al. (2014a) found that $1.8 \mathrm{t}$ were caught in coastal competitive fishing events off Sergipe in 1998. However, details on the catch composition were not provided by recreational fishers, except for the heaviest specimens caught: Rajiformes, Ariidae, Tetraodontidae, Diapterus spp., Caranx hippos (L.), Conodon nobilis (L.), Centropomus spp., Trachinotus spp. and Lobotes surinamensis (Bloch).

Moro (2008) estimated a CPUE for snooks caught in competitive fishing events in the state of Paraná of about $328 \mathrm{~g} \mathrm{boat}^{-1} \mathrm{~h}^{-1}$. Based on specimens sampled in these events, it was also possible to estimate growth parameters for $C$. parallelus. In the state of Rio Grande do Sul, the Mampituba River has also been attracting recreational fishers targeting snooks, which include catches during competitive fishing events (UGAPE 2015).

A total of 117 events occurred in fresh waters in 2013, which were mostly promoted by government institutions. Missing values are more common for these events, which are mostly catch-and-release (82\%), use artificial bait $(89 \%)$ and are boat-based $(71 \%)$. The maximum number of fishes is set at 3-12 per fisher, depending on the event, which is a feature that is never observed in marine events. For most events, 1-5 species are defined as the target: Cichla spp., Micropterus salmoides (Lacepède), P. mesopotamicus, Plagioscion spp., H. malabaricus, C. rendalli and/or O. niloticus, Salminus spp., Astyanax spp., Serralmus spp., Oncorhynchus mykiss (Walbaum) and Pseudoplatystoma fasciatum (L.). A total of 10-2400 recreational fishers have participated in these events (1-4 fishers per team).

\section{Patterns among licensed recreational fishers}

A total of 401550 licences were issued in 2013 for foreigner and Brazilian recreational fishers (263 222 records after eliminating errors in the licence database). The CA analysis separated the north-eastern region from the other four regions due to the following characteristics (Fig. 5): fishers fish mostly in the ocean, mangroves and beaches, but less in rivers; they acquire mainly type A licences (shore-based), and thus, fishing guides are not necessary; fishing expenditures are minimal (US\$ 111 in average); and most fishers never release the fishes. A total of 78 type-C licences were issued in 2013 despite being eliminated in 2012.

In countries such as the USA, catches originating from recreational fisheries keep increasing (Ihde et al. 2011). However, Arlinghaus (2014) argued that societal-level values shift when urbanisation increases and values such as the conservation of wildlife are emphasised. Thus, the effect of the Human Development Index (HDI) on the percentage of recreational anglers stating that they always or only sometimes release fishes was tested for each Brazilian state using the licences issued in 2013. No general association between these two variables was found (Fig. 6). However, the lowest HDI was observed for the state of Alagoas, in the north-eastern region, where only $55.1 \%$ of recreational fishers release fish at least occasionally. On the other hand, the highest HDIs were found for the Federal District, São Paulo, Santa Catarina and Rio de Janeiro, all of which have a high proportion of fish releasers $(>88.5 \%)$. HDI is not the only factor influencing catch-and-release behaviour, but there are also many others including historical and contemporary norms and the conservation status of species. However, HDI was the only one that could be easily analysed on a national scale with available data. It is important to follow changes in this relationship through time and access the effect of other factors locally.

\section{Governance of recreational fisheries}

According to the Brazilian Constitution, natural resources from the ocean, rivers and lakes belong to the State. Federal and state laws regulate fisheries in these areas. The latter occurs only in waters under the domain 


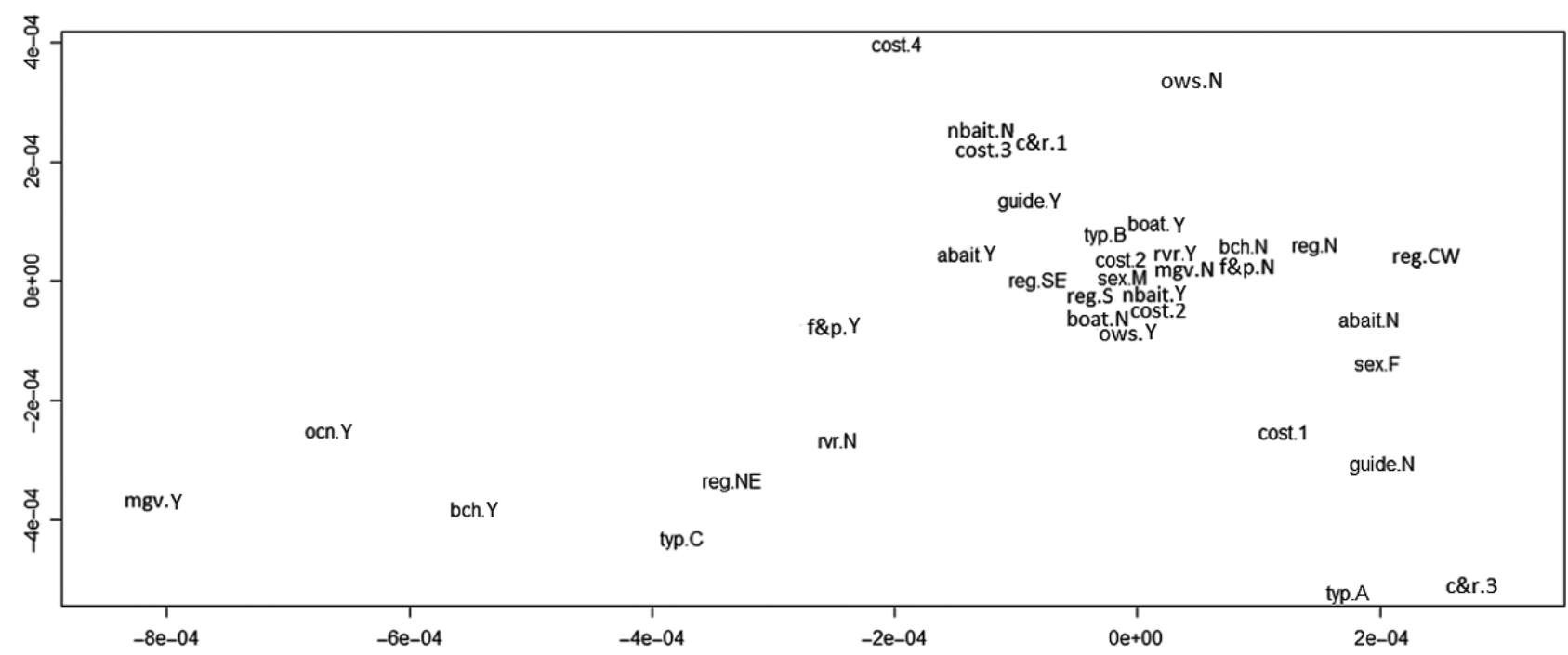

Figure 5. Results of the correspondence analysis applied to 263222 licences issued in all of the Brazilian states in 2013. Mgr = mangrove, ocn = oceanic fishery, bch $=$ beach (coastal fishery), rvr = river, reg = region $(\mathrm{N}=$ north, $\mathrm{NE}=$ north-east, $\mathrm{SE}=$ south-east, $\mathrm{S}=\mathrm{south}, \mathrm{CW}=$ centre-west $)$, cost $(1=$ very low to $4=$ very high $)$, nbait $=$ natural bait, abait $=$ artificial bait, f\&p $=$ fish-and-pay, c\&r $=$ catch-and-release $(1=$ always, $2=$ sometimes, $3=$ never $)$, ows $=$ fish in their own state, boat = boat-based fisher, guide $=$ make use of fishing guides, sex $=$ masculine $(\mathrm{M})$ or feminine $(\mathrm{F})$, and $\mathrm{Y}=$ Yes, $\mathrm{N}=$ No.

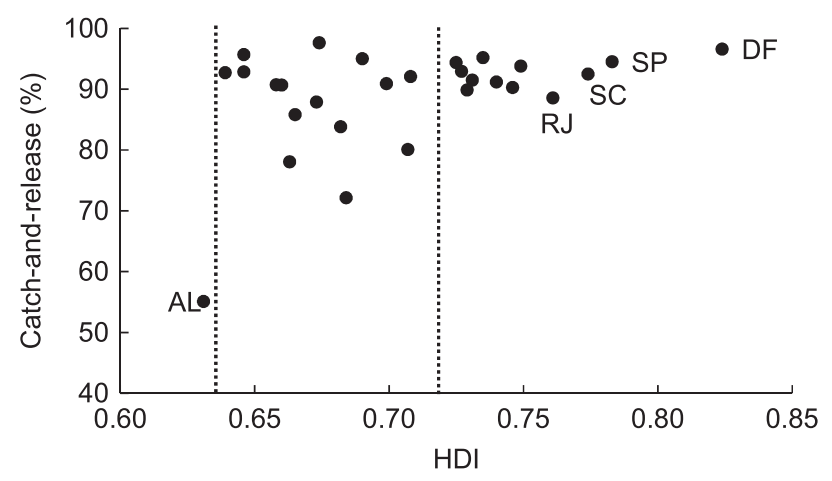

Figure 6. Relationship between the percentage of recreational fishers always or sometimes releasing fish, and the Human Development Index (HDI) for each Brazilian state (including the Federal District - DF). AL: Alagoas, RJ: Rio de Janeiro, SC: Santa Catarina, and SP: São Paulo.

of its states, and state legislation should be stricter than federal. On the national level, recreational and commercial fisheries have always been managed by the same institution. Thus, when the first recreational fisheries regulation was introduced in 1934, fisheries management was under the department of the Ministry of Agriculture (MA). Later, the more autonomous SUDEPE (Superintendence for Fisheries Development) was responsible for fisheries management, but still under the MA. In 1989, the Brazilian Institute for the Environment and Renewable Resources (IBAMA) was created and became responsible for managing Brazilian fisheries. In 2009, the Ministry of Fisheries and Aquaculture (MPA) was founded and shared that responsibility with the Ministry of the Environment (MMA). In October 2015, the MPA was extinguished and fisheries management is back again under the MA.

The first Brazilian legal instrument concerning recreational fisheries was created in 1934, which established a mandatory licence for recreational fishers and prohibited selling their catches. In the 1960s, Law N.5197 (1967), Decree N.221 (1967, known as Fishing Law), and Decree N.65005 (1969) were established during a period characterised by rapid development in both commercial (SUDEPE/PDP 1976) and recreational fisheries. Decree N.221 established a list of the permitted fishing gears (excluding any kind of seine) and a bag limit of $50 \mathrm{~kg}$ plus one fish for marine and fresh waters. In 1989, this limit was reduced to $30 \mathrm{~kg}$ plus one fish. In 2003, the bag limit was decreased again to $10 \mathrm{~kg}$ when fishing in fresh water and $15 \mathrm{~kg}$ in marine water, plus one fish (any species), which is currently the adopted regulation. In 1988, Federal Law N.7679 introduced the minimum size and closed seasons and areas as regulatory measures.

In relation to fresh water, all of the measures defined above were intended to be basin-based (although not mandatory). By 2009, seven out of the twelve major Brazilian basins had their own stricter set of rules. Overall, the generic regulation applies to the remaining states. In 2009, Federal Law N.11959, known as the New Fishing Law, established that all fishery and aquaculture regulations were supposed to be defined using a co-man- 
agement approach (between MPA and MMA). These regulations could include, among other measures: access regimes, total allowable catch, sustainable fishing effort, closed seasons and areas, catch size, allowed fishing gears and methods, and protection of individuals during their reproduction process or recovery.

Two national meetings, the First National Meeting on Recreational Fisheries (MPA 2010) and the National Seminar on Prospecting Demand of Supply Chain in Fisheries, were organised by the Brazilian government in recognition of the need to increase societal participation in the management of recreational fisheries (Prysthon et al. 2012). The first aimed to identify demands and priorities established by democratically elected representatives of the recreational fisheries sector for all Brazilian states, and the second one concentrated on demands of research and development identified by scientists and managers. However, recreational fishers are not organised into strong, well-represented entities, and are often not properly represented before management decisions are made. Contrary to the legal framework establishing co-management in Brazil in 2009, the government/society council that should address recreational fisheries management has never been put into practice. Finally, the participation of experts in fisheries and fish populations in discussions regarding recreational fisheries is very restricted, more so than for commercial fisheries. Thus, decisions are made based on industry operators, associations without scientific support, and politicians, which has contributed to the existence of a management system deprived of a scientific basis in many cases.

\section{Challenges and future direction}

The analysis of Brazilian recreational fisheries resulted in the compilation of information on several initiatives spread throughout the entire country and showed some important insights on the future direction of recreational fisheries.

- While the two recent national meetings indicated that the government is increasingly recognising the importance of recreational fisheries, the relevance of recreational fisheries research should also be understood for the establishment of a sound management plan in cognisance with other fishing sectors (artisanal, industrial and subsistence) and stakeholders. This includes the economic assessment of recreational fisheries because currently, there are only a few local studies available.

- In many regions, commercial and recreational fishers share common fishing grounds and target species. Thus, actions to reduce conflicts and maintain the health of fish stocks are required, including zoning, effective supervi- sion, training of fishing guides and fishers, and expansion of the fisheries monitoring system;

- Recreational fishers should be informed or reminded of 'good fishing practices' through education programmes, and these would include impacts of stocking, legal minimum and maximum size, and the danger of the introduction and translocation of species. The translocation of Cichla cf monoculus, Astronotus ocellatus (Agassiz) and Pygocentrus nattereri Kner into the River Doce State Park led to decreased fish diversity with the disappearance of some species and reduction of the mean weight of others (Latini \& Petrere 2004 and references therein). IBAMA regulation N.145-N (October 29, 1998) on introduction and translocation should be revised to include recreational species.

- Recreational fisheries cannot be referred to as a homogenous group with similar behaviour and needs; thus, subgroups should be defined along with the need to conduct research for those specific subgroups accessed, for example freshwater vs marine fishers, competition participants vs non-participants and spearfishers. The latter have been marginalised by some conservationist groups contrary to the practice of spearfishing.

- If catch-and-release is to be promoted, studies on the lethal and sublethal effects of releasing the species caught in Brazilian waters are necessary through partnerships.

- Remodelling the questionnaire provided together with the fishing licence is needed where all fields should be required and validations introduced to avoid the high number of errors found in this study;

- The federal government is expected to move towards a system of collection of catch statistics that includes those originating from recreational fisheries, following an international trend (see recommendation in FAO 2012), which is a major challenge considering that the system for compiling commercial catches has collapsed since 2008. If a new or remodelled system is to be created, recreational fisheries should be embedded from the beginning, including partnerships among fishing clubs/ associations, associations of commercial fishers, MPA, IBAMA, Instituto de Pesca and hydroelectric companies with guaranteed funds;

- Bait-fishing has emerged as a new subsector in commercial fisheries to meet the demand of recreational fishers in some regions. However, there is a need for the regulation of this activity, including a system of collection of the catch statistics.

It should be stressed that this is the first time that Brazilian scientists have worked together to analyse Brazilian marine and freshwater recreational fisheries. This undertaking was only possible due to the 7th World Recreational Fishing Conference hosted in Brazil in 2014 (the 
first time in South America), which permitted most of the Brazilian recreational fishing-related scientific community to unite together with an international group of specialists. However, the participation of emerging economies was still timid. Organising all of the diverse information available was not an easy task, and scientists should move towards regional initiatives to fill missing information gaps using similar methodologies and later move towards initiatives that also involve other countries in South America.

\section{References}

AES-Tietê (2011) Programa de Manejo e Conservação de Bacias Hidrográficas e Reservatórios- Ictiofauna. Rel. 051/12. JanDec/2011. 52 pp.

Agostinho A.A., Gomes L.C., Suzuki H.I. \& Júlio M.L. Jr (2003) Migratory fishes of the Upper Paraná River Basin, Brazil. In: J. Carolsfeld, B. Harvey, C. Ross \& A.Baer (eds) Migratory fishes of South America: biology, fisheries and conservation status. Ottawa: World Fisheries Trust: International Development Research Centre; Washington, D.C.: International Bank for Reconstruction and Development/ The World Bank, pp. 19-98.

Albuquerque S.P., Catella A.C., Campos F.L.R. \& Santos D.C. (2013) Sistema de Controle de Pesca de Mato Grosso do Sul SCPESCA/MS19-2012, Corumbá: Embrapa Pantanal; Campo Grande, Mato Grosso do Sul, SEMAC, IMASUL, 54 pp.

Amorim A.F. \& Silva B.O. (2005) Game fisheries off São Paulo state coast, in Brazil (1996-2004). Collective Volume of Scientific Papers, International Commission for the Conservation of Atlantic Tunas (ICCAT) 58, 1574-1588.

Amorim A.F., Arfelli C.A., Pimenta E., Fina N.D., Silva N.P. \& Silva B.P. (2009) Sailfish sports fishing off Rio de Janeiro state, Brazil (2002-2008). Collective Volume of Scientific Papers, International Commission for the Conservation of Atlantic Tunas (ICCAT) 64, 1909-1914.

Angelo P.G. \& Carvalho A.R. (2007) Valor recreativo do rio Araguaia, região de Aruanã, estimado pelo método do custo de viagem. Acta Scientarium Biological Sciences 29, 421-428.

Anon (1970) Campeonato brasileiro de caça submarina. Revista Pescatur 1, 48.

Anon (2015) Bíblia do pescador. O anuário brasileiro de estudo da pesca esportiva. Editora Um, São Paulo. 400 pp.

Arfelli C.A., Amorim A.F. \& Graça-Lopes R. (1994) Billfish sport fishery off Brazilian coast. Collective Volume of Scientific Papers, ICCAT 41, 214-217.

Arlinghaus R. (2014) Social value change and sustainable fisheries. In: E.T. Silva, A.L. Ferreira \& M. Furlaneto (eds) 7th World Recreational Fishing Conference. Change, Transformation and Adaptation in Recreational Fishing. Campinas: Edições Leitura Crítica, pp. 25.

Arrolho S.A.S. \& Muniz C.C. (2011) Monitoramento da ictiofauna em área de desenvolvimento de pesca esportiva e as possíveis influências das usinas hidroelétricas no rio Teles
Pires, Alto Tapajós. In: Caderno de Resumos do I Simpósio Nacional de Pesca Esportiva, Belém, pp. 18-24. Available at: www.cpap.embrapa.br/pesca/online/PESCA2011_ISINPE.pdf. Accessed in May, 2015.

Barcellini V.C., Motta F.S., Martins A.M. \& Moro P.S. (2013) Recreational anglers and fishing guides from an estuarine protected area in southeastern Brazil: socioeconomic characteristics and views on fisheries management. Ocean \& Coastal Management 76, 23-29.

Barra C.S. \& Crepaldi D.V. (2014) Levantamento socioambiental dos impactos e da viabilidade da atividade de turismo de pesca esportiva na área de uso tradicional das comunidades representadas pela ACIBRN - Rio Marié, Amazonas, Terras Indígenas Médio Rio Negro I e II. Relatório Técnico do IBAMA/ISA.

Barra C.S. \& Dias C. (2013) Barcelos Indígena e Ribeirinha um perfil socioambiental. São Paulo: Instituto Socioambiental - ISA.

Barros L.C., Santos U., Zanuncio J.C. \& Dergam J.A. (2012) Plagioscion squamosissimus (Sciaenidae) and Parachromis managuensis (Cichlidae): a threat to native fishes of the Doce River in Minas Gerais, Brazil. PLoS ONE 7, e39138.

Barroso H. (2002) Tempos da pesca. Rio de Janeiro, Brazil: Ediouro, 248 pp.

Basaglia T.P. \& Vieira J.P. (2005) A pesca amadora recreativa de caniço na Praia do Cassino, RS: necessidade de informações ecológicas aliadas à espécie alvo. Brazilian Journal of Aquatic Science and Technology 9, 25-29.

Belruss C.G. (2014) Pesca recreativa no complexo baía-estuário de Santos - São Vicente (SP, Brasil). Instituto de Pesca do Estado de São Paulo, Master thesis. 56 pp.

Carvalho A.R. \& Medeiros E.R. (2005) Levantamento socioeconômico e da composição de espécies entre os turistas que praticam a pesca recreativa no Rio Araguaia, região de Aruanã - GO. Revista Saúde e Ambiente 6, 23-31.

Castro P.M.G., Maruyama L.S., Menezes L.C.B. \& Mercante C.T.J. (2006) Perspectivas da atividade de pesqueiros no Alto Tietê: contribuição à gestão de usos múltiplos da água. Boletim do Instituto de Pesca 32, 1-14.

Castro P.M.G., Alves da Silva M.E.P., Maruyama L.S. \& Paiva P. (2009) Produção pesqueira do Reservatório Billings (Bacia do Alto Tietê-SP), nos anos de 2005, 2006 e 2007. Série Relatórios Técnicos, São Paulo 38, 1-10.

Castro P.M.G., Silva M.H.C., Faria-Pereira L.P., Menezes L.C.B. \& Maruyama L.S. (2014) Live-bait fishing: an alternative to artisanal fishermen in the middle Tietê River Basin, Brazil. Proceedings of the 2nd World Small-Scale Fisheries Congress, September 21-26, 2014. Merida, Mexico.

Catella A.C. (2007) Uso plural dos recursos pesqueiros como estratégia para sua conservação. $1^{\circ}$ Congresso Brasileiro de Produção de Peixes Nativos de Água Doce. Dourados, MS, Embrapa Agropecuária Oeste, Corumbá, Embrapa Pantanal, CD-ROM.

Catella A.C., Mascarenhas R.O., Albuquerque S.P., Albuquerque F.F. \& Theodoro E.R.M. (2008) Sistemas de estatísticas 
pesqueiras no Pantanal, Brasil: aspectos técnicos e políticos. Pan-American Journal of Aquatic Sciences 3, 174-192.

Chiappani L.H.B. (2006) Caracterização e avaliação da atividade de pesca amadora na praia de Camburi, Vitória - ES. Departamento de Ecologia e Recursos Naturais. Vitória, Universidade Federal do Espírito Santo, Undergraduate thesis. $50 \mathrm{pp}$.

Condini M.V.L., Garcia A.M. \& Vieira J.P. (2007) Descrição da pesca e perfil sócio-econômico do pescador da garoupa verdadeira Epinephelus marginatus (Lowe) (Serranidae: Epinephelinae) no Molhe Oeste da Barra de Rio Grande, Rio Grande do Sul, Brasil. Pan-American Journal of Aquatic Sciences 2, 279-287.

Crepaldi D.V. \& Machado M.L. (2010) Avaliação rápida dos estoques de Cichla do rio Jauaperi no trecho compreendido entre sua foz e a Reserva Indígena Waimiri Atroari-AM e RR (Parte I). Prospecção do potencial para pesca amadora do rio Jauaperi no trecho compreendido entre sua foz e a Reserva Indígena Waimiri Atroari-AM e RR (Parte II). IBAMA/ MMA, Brasília.

DPA (1946) Produção marítima do estado de São Paulo. São Paulo: Secretaria da Agricultura, Indústria e Comércio, 122 pp.

FAO (2012) Recreational Fisheries. FAO Technical Guidelines for Responsible Fisheries. N.13. Rome: FAO, 176 pp.

Fernandes R., Gomes L.C. \& Agostinho A.A. (2003) Pesquepague: negócio ou fonte de dispersão de espécies exóticas? Acta Scientiarum: Biological Sciences 25, 115-120.

FIPERJ/MPA/UFRJ (undated) Monitoramento da pesca industrial no Rio de Janeiro - Capacitação, pesquisa e gestão. Rio de Janeiro, FIPERJ/MPA/UFRJ.

Frédou T., Figueiredo Filho L.D., Torres D.G., Ferreira P.R.C., Souza E.G. \& Lopes K.S. (2008) Diagnóstico, tendência, potencial e políticas públicas para o desenvolvimento da pesca esportiva. Belém: Universidade Federal do Pará, 137 pp.

Freire K.M.F. (2005) Recreational fisheries of northeastern Brazil: inferences from data provided by anglers. In: G.H. Kruse, V.F. Gallucci, D.E. Hay, R.I. Perry, R.M. Peterman, T.C. Shirley, P.D. Spencer, B. Wilson \& D. Woodby (eds) Fisheries Assessment and Management in Data-Limited Situations. Fairbanks, Alaska: University of Alaska Fairbanks, Alaska Sea Grant College Program, pp. 377-394.

Freire K.M.F., Machado M.L. \& Crepaldi D. (2012) Overview of inland recreational fisheries in Brazil. Fisheries 37, 484-494.

Freire K.M.F., Bispo M.C.S. \& Luz R.M.C.A. (2014a) Competitive marine fishery in the state of Sergipe. Acta Fisheries and Aquaculture 2, 59-72.

Freire K.M.F., Teles S.C.S., Adelino G. \& Machado M.L. (2014b) First analysis of recreational oceanic fishing off northeastern Brazil. In: E.T. Silva, A.L. Ferreira \& M. Furlaneto (eds) 7th World Recreational Fishing Conference. Change, Transformation and Adaptation in Recreational Fishing. Campinas: Edições Leitura Crítica, pp. 90-91.

Freitas C.E.C. \& Rivas A.A.F. (2006) A pesca e os recursos pesqueiros na Amazônia Ocidental. Ciência e Cultura 58, 3032.
Froese R. \& Pauly D. (2015) FishBase. Version 10/2015. Available at: www.fishbase.org. Accessed in December 2015.

Garrone-Neto D., Mendonça J.T., Moro P.S. \& Motta F.S. (2014) Recreational fishing in the south coast of the state of São Paulo. In: E.T. Silva, A.L. Ferreira \& M. Furlaneto 7th World Recreational Fishing Conference. Change, Transformation and Adaptation in Recreational Fishing. Campinas: Edições Leitura Crítica, pp. 47.

Greenacre M.J. \& Blasius J. (1994) Correspondence Analysis in the Social Sciences: Recent Developments and Applications. London, San Diego: Academic Press, 370 pp.

Harayashiki C.A.Y., Furlan F.M. \& Vieira J.P. (2011) Perfil sócio-econômico dos pescadores da Ponte dos Franceses, Rio Grande, RS, Brasil. Boletim do Instituto de Pesca 37, 93-101.

IBAMA (2012) IBAMA desativa empreendimento turístico ilegal em terra indígena. Available at: http://www.ibama.gov.br/ publicadas/ibama-desativa-empreendimento-turistico-ilegal-emterra-indigena. Accessed in May, 2015.

IBAMA (2014) IBAMA intensifica combate aos crimes ambientais em terras indígenas de Mato Grosso. Available at: http://www.ibama.gov.br/publicadas/ibama-intensifica-combateaos-crimes-ambientais-em-terras-indigenas-de-mato-grosso. Accessed in May, 2015.

Ihde T.F., Wilberg M.J., Loewensteiner D.A., Secor D.H. \& Miller T.J. (2011) The increasing importance of marine recreational fishing in the US: Challenges for management. Fisheries Research 108, 268-276.

IPAAM (2001) Plano de gestão da pesca esportiva no Amazonas: versão preliminar. Manaus: Instituto de Proteção Ambiental do Estado do Amazonas, 86 pp.

ISA (2013) Monitoramento participativo da pesca no Médio Rio Negro é tema de oficinas e capacitação de pesquisadores. Instituto Socioambiental. Available at: http://siteantigo.socioambiental.org/nsa/detalhe?id=3725. Accessed in December, 2014.

Latini A.O. \& Petrere M. Jr (2004) Reduction of a native fish fauna by alien species: an example from Brazilian freshwater tropical lakes. Fisheries Management and Ecology 11, 71-79.

Lewis D., Braun A.S. \& Ferreira N.F. (1999) Relative seasonal fish abundance caught by recreational fishery on Cidreira Pier, southern Brazil. Journal of Applied Ichthyology 15, 149-151.

Magalhães J.V.C. (1863) Viagem ao Araguaya. Goyaz: Typographia Provincial. Available at: http:// etnolinguistica.wdfiles.com. Accessed in November, 2014.

Maruyama L.S., Espíndola E.L.G., Pereira L.P.F., Bueno A.S., Almeida I.M.T. \& Castro P.M.G. (2014) Ichthyofauna in Guarapiranga dam (São Paulo, Brazil), as a resource of funds for recreational and professional fishing. In: E.T. Silva, A.L. Ferreira \& M. Furlaneto (eds) 7th World Recreational Fishing Conference. Change, Transformation and Adaptation in Recreational Fishing. Campinas: Edições Leitura Crítica, pp. 48.

Mendonça J.T. \& Cordeiro A.G. (2010) Estatística pesqueira do litoral sul de São Paulo - Metodologia e resultados. In: R.B. Silva \& L.C. Ming (eds) Relatos de pesquisas e outras 
experiências vividas no Vale do Ribeira. Jaboticabal: Maria de Lourdes Brandel, pp. 171-190.

Mendonça J.T. \& Parada I.S. (2014) Dynamics of recreational and professional fishing in Estuary Cananéia and Iguape, São Paulo State, Brazil. In: E.T. Silva, A.L. Ferreira \& M. Furlaneto (eds) 7th World Recreational Fishing Conference. Change, Transformation and Adaptation in Recreational Fishing. Campinas: Edições Leitura Crítica, pp. 39.

Menezes A.A.S., Lin C.F., Silva C. \& dos Santos R.A. (2012) Aspectos socioeconômicos relacionados à pesca amadora de robalo (Centropomus undecimalis e C. parallelus) na Baía da Babitonga, Santa Catarina, Brasil. Revista CEPSUL Biodiversidade e Conservação Marinha 3, 22-44.

Moro P.S. (2008) Prospecção do estoque de robalo-peva (Centropomus parallelus) no litoral do Paraná, através da pesca esportiva. Universidade Federal do Ceará, Master thesis, $132 \mathrm{pp}$.

Moro P.S., Mendonça J. \& Motta F.S. (2010) Diagnóstico e caracterização da pesca amadora no Complexo Estuarino-Lagunar de Iguape, Cananéia e Ilha Comprida, litoral sul do Estado São Paulo. Relatório final de concessão de bolsa de pesquisa, Conservação Internacional, Cananéia, São Paulo. 60 pp.

MPA (2009) Lei N.11959, de 29 de junho de 2009. Dispõe sobre a Política Nacional de Desenvolvimento Sustentável da Aquicultura e da Pesca, regula as atividades pesqueiras, revoga a Lei N.7679, de 23 de novembro de 1988, e dispositivos do Decreto-Lei N.221, de 28 de fevereiro de 1967, e dá outras providências. Available at: http://www.planalto.gov.br/ ccivil_03/_ato2007-2010/2009/Lei/L11959.htm. Accessed in June 2015.

MPA (2010) I Encontro Nacional da Pesca Amadora "Construindo a política da pesca amadora". Final document. Brasília: MPA, 28 pp.

Nascimento F.P. (2008) Aspectos biológicos e sócio-econômicos da pesca esportiva marinha em Ilhéus - Bahia, Ilhéus, Universidade Estadual de Santa Cruz, Undergraduate thesis. 47 pp.

Nunes J.A.C.C., Medeiros D.V., Reis-Filho J.A., Sampaio C.L.S. \& Barros F. (2012) Reef fishes captured by recreational spearfishing on reefs of Bahia State, northeast Brazil. Biota Neotropica 12, 179-185.

Oliveira A.G., Bastos A.T., Fontenele R.E.S. \& Moura H.J. (2014) Avaliação de políticas públicas de desenvolvimento local: o caso do Projeto Castanhão. In: Anais do Encontro Internacional sobre Gestão Empresarial e Meio Ambiente XVI Engema, 2014, São Paulo, pp. 1-17.

Peixer J. (2008) Características e valoração da pesca esportiva, profissional e do turismo da Cachoeira de Emas, no Rio MogiGuaçu/SP. Rio Claro, São Paulo, UNESP, Instituto de Biociências, PhD thesis: 169 pp.

Pereira J.M.A., Petrere M. Jr \& Ribeiro-Filho R.A. (2008) Angling sport fishing in Lobo-Broa Reservoir (Itirapina, SP, Brazil). Brazilian Journal of Biology 68, 721-731.

Peres M.B. \& Klippel S. (2005) A pesca amadora na costa da plataforma sul. In: C.M. Vooren \& S. Klippel (eds) Ações para a conservação de tubarões e raias no sul do Brasil. Porto Alegre: Igaré, pp. 200-212.

Petrere M. Jr, Agostinho A.A., Okada E.K. \& Júlio H.F. Jr (2002) Review of the fisheries in the Brazilian portion of the Paraná/Pantanal basin. In: I.G. Cowx (ed.) Management and Ecology of Lake and Reservoir Fisheries. Bodman, UK: Fishing New Books, pp. 123-143. doi: 10.1002/ 9780470995679.ch11

PNUD/IPEA/FJP (2013) Atlas do desenvolvimento humano no Brasil. Programa das Nações Unidas para o Desenvolvimento (PNUD), Instituto de Pesquisa Econômica Aplicada (IPEA) and Fundação João Pinheiro (FJP). Available at: http:// www.atlasbrasil.org.br/2013/. Accessed in November, 2014.

Prysthon A.S., Rosa D.K., Lima A.F., Sousa D.N., Luis D.B., Mataveli M. et al. (2012) Relatório técnico do Seminário Nacional de Prospecção de Demandas da Cadeia Produtiva da Pesca, Vol. 1, 1st edn. Brasília: Embrapa, 88 pp.

$\mathrm{R}$ Core Team (2014) R: A Language and Environment for Statistical Computing. Vienna, Austria: R Foundation for Statistical Computing. Available at: http://www.R-project.org/. Accessed in November 2014.

Salazar Filho H.O., Andretta R.A. \& Nogueira E.M. (2005) Diagnóstico preliminar do potencial de desenvolvimento da atividade de pesca esportiva na região do baixo Rio Branco, estado de Roraima. Boletim Técnico-Científico do CEPNOR 5, 173-195.

Santos F.A. (undated) Síntese dos indicadores de turismo do Amazonas 2003/2011. Amazonastur. Available at: http:// www.visitamazonas.am.gov.br/site/arquivos/download/publicac oes/sintese-dos-Indicadores-de-Turismo-AM-2003_2011.pdf. Accessed in May, 2015.

Santos R.B. \& Freire K.M.F. (2014) Inland competitive fishing in Brazil. In: E.T. Silva, A.L. Ferreira \& M. Furlaneto (eds) 7th World Recreational Fishing Conference. Change, Transformation and Adaptation in Recreational Fishing. Campinas: Edições Leitura Crítica, pp. 45.

Santos R.A., da Câmara J.J.C., Campos E.C., Vermulm H. Jr \& Giamas M.T.D. (1995) Considerações sobre a pesca profissional e a produção pesqueira em águas continentais do Estado de São Paulo. Boletim Técnico do Instituto de Pesca 19, 1-32.

Schork G., Mottola L.S.M. \& Silva M.H. (2010) Diagnóstico da pesca amadora embarcada na região de São Francisco do Sul (SC). Revista CEPSUL - Biodiversidade e Conservação Marinha 1, 8-17.

SUDEPE/PDP (1976) Sistema nacional de estatísticas de pesca do Brasil. FAO Série Documentos Técnicos 12, 1-9.

Thomé-Souza M.J.F., Maceina M.J., Forsberg B.R., Marshall B.G. \& Carvalho A.L. (2014) Peacock bass mortality associated with catch-and-release sport fishing in the Negro River, Amazonas State, Brazil. Acta Amazonica 44, 527-532.

Tsuruda J.M., do Nascimento R.B., Barrella W., Ramires M. \& Rotundo M.M. (2013) Fishing and socio-economic profile of sportive anglers of Galhetas Tip, Asturias Beach-Guarujá (SP). Unisanta BioScience 2, 22-34.

Tubino R.A., Monteiro-Neto C., Moraes L.E.S. \& Paes E.T. (2007) Artisanal fisheries production in the coastal zone of 
Itaipu, Niterói, RJ, Brazil. Brazilian Journal of Oceanography 55, 187-197.

Tubino R.A., Couto B.R. \& Monteiro-Neto C.M. (2013) Atividade de pesca recreativa desenvolvida na área de proteção ambiental de Guapimirim, Baía de Guanabara, RJ. Proceedings of "Uso Público em Unidades de Conservação" 1, 152-163.

UGAPE (2015) União Gaúcha de Pesca Esportiva. Available at: www.ugape.com.br/. Accessed in May 2015.

Venturieri R. (2002) "Pesque-pague" no Estado de São Paulo: vetor de desenvolvimento da piscicultura e opção de turismo e lazer, Programa Nacional de Desenvolvimento da Pesca Amadora (PNDPA), Projeto PNUD BRA/97/012, EMBRATUR \& MMA: 168 pp.
Zeinad A.K. \& Prado R.A. (2012) Peixes fluviais do Brasil. Campinas: Pescaventura, 360 pp.

\section{Supporting Information}

Additional Supporting Information may be found in the online version of this article:

Annex S1 Selected translated questions from the recreational fishing license included in the analysis of the fishers' profile and their respective answer options.

Table S1 Descriptive parameters of the Brazilian recreational fisheries. 